\title{
Biotechnology and Agriculture
}

Akinruli Samuel Ayobami, Azevedo Valesca, Barbosa Francisco Vidal and Azevedo Vasco*

Universidade Federal De Minas Gerais (UFMG), Brazil

\begin{abstract}
Here, we provide a comprehensive insight into current advances in the use of modern biotechnology in agriculture. Considering that biotechnology involves the use of scientific and engineering principles in the processing of materials by biological agents to provide goods and services. This study does not only take a historical retrace of biotechnology into account but considers the pros and cons of the use of biotechnology in attending the need for global food production as well as the challenges thereof.
\end{abstract}

Keywords: Biotecnology; Agriculture; Cropping systems; Agricultural Production Systems

\section{Introduction}

Agriculture could be seen as the use of cultivation toward achieving life sustenance. However, cultivation includes that of animals, plants, fungi and other life forms for food, fiber, and other products. The study of agriculture is known as agricultural science, and also observed in certain species of ant and termite. It could be holistically refer to human activities as it was the key factor in the rise of sedentary human civilization, whereby farming of domesticated species created food surpluses that nurtured the development of civilization.

Biotechnology, on the other hand, is the use of scientific and engineering principles in the biological materials processing of agents in order to provide goods and services for human use. There has been a strong tie between its existence and societal development. In other words, history has it that biotechnology has been principally associated with food, addressing such provision, and as such, acting as solutions to solving problems related malnutrition and famine in societies. Nonetheless, Biotechnology has recently been coupled with the development of vital drugs.

Globally, the systems of agriculture have advanced tremendously owing to the advancement of technological knowhow. More so, recent centuries marked the peak of the agricultural embracement with the use of modern Biotechnology. Although, agricultural practices such as irrigation, crop rotation, fertilizers, and pesticides were developed long ago

The history of agriculture has played a major role in human history, as agricultural progress has been a crucial factor in worldwide socioeconomic change and evident ideologically in cultural advancement, and social organization such as hunter-gathering, settlements, arts, architecture, law etc. Furthermore, human and social science researcher of various specialties have long argued civilization emerged from agricultural development and as such its attainment owed to agricultural advancement.

\section{Agricultural Production Systems}

Agricultural Activities or production can be divided into two major systems called 'Cropping system and the livestock production system.

\section{The cropping systems}

The Cropping systems are of different kinds and the farm's choice is often determined by considering the constraints and availability of some motivating factors. These could be traced to regional and geographical structure, climate, government policies, socio-economic and political factors etc. However, cropping system is also referred to as cultivation system which includes the shifting cultivation system and annual cultivation system. The shifting cultivation system involves slashing and burning of the forests to bring about the release of nutrients on the soil for annual and perennial crops cultivation. The annual crop cultivation does not necessarily require the fallow period, while it appears preferable in the perennial cultivation whereby the tampered land is sequentially left fallow for forest to germinate. During this period, famers move to another piece of land to return after ten to twenty years. When necessary, farmers may choose to reduce the fallow period. However, this requires a boost in nutrient using fertilizer or manure and pest control which is also applicable to monocultures and polycultures at large scale or large acreage where nutrient tends to be relatively low as the biodiversity therein.

Agricultural practices: Agricultural practices are the methods through which agriculture production processes is performed. These practices include;

Tillage: Tillage this involves plowing soil in preparation for planting, incorporation of nutrient or pest control. The intensity of the tillage practice varies from conventional to no-till and may improve productivity through soil warming, weeds controlling and incorporating fertilizer, provoking organic matter decomposition and consequently releasing $\mathrm{CO} 2$ which brings about reduction in the abundance and diversity of soil organisms. However, soil may be more exposed to erosion $[1,2]$.

Pest control: Pest control involves the management of weeds, insects/mites, and diseases. Here, chemical (pesticides), biological (bio-control), mechanical (tillage), and cultural practices are employed. Cultural practices include crop rotation, culling, cover crops, intercropping, composting, avoidance, and resistance. "Integrated pest management attempts to use all of these methods to keep pest populations below the number which would cause economic loss, and recommends pesticides as a last resort" [3].

*Corresponding author: Azevedo Vasco, Universidade Federal De Minas Gerais (UFMG), Brazil, Belo Horizonte, Minas Gerais, CP 486 CEP 31270-901, Brazil, Tel \& Fax: 0055313409 2610; E-mail: vascoariston@gmail.com

Received May 30, 2013; Accepted July 28, 2013; Published August 06, 2013

Citation: Ayobami AS, Valesca A, Vidal BF, Vasco A (2013) Biotechnology and

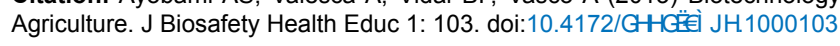

Copyright: (c) 2013 Ayobami AS, et al. This is an open-access article distributed under the terms of the Creative Commons Attribution License, which permits unrestricted use, distribution, and reproduction in any medium, provided the original author and source are credited. 
Nutrient management: Nutrient management includes both the source of nutrient inputs for crop and livestock production, and the method of utilization of manure produced by livestock. Nutrient inputs can be chemical inorganic fertilizers, manure, green manure, compost and mined minerals [4]. Crop nutrient use may also be managed using cultural techniques such as crop rotation or a fallow period [5,6]. Manure is used either by holding livestock where the feed crop is growing, such as in managed intensive rotational grazing, or by spreading either dry or liquid formulations of manure on cropland or pastures.

Water management: Water management is where rainfall is insufficient or variable, which occurs to some degree in most regions of the world [7]. Some farmers use irrigation to supplement rainfall. In other areas such as the Great Plains in the U.S. and Canada, farmers use a fallow year to conserve soil moisture to use for growing a crop in the following year [8]. Agriculture represents $70 \%$ of freshwater use worldwide.

Livestock production systems: Livestock production systems involves animal husbandry which includes the breeding and raising of species either for work and companionship or for production of food like meat, milk, eggs, or wool. These animals include cattle, horses, mules, oxen, camels, llamas, alpacas, and dogs, goats, sheep etc. Animal husbandry can be classified by the methods of feeding which include grassland based, mixed, and landless livestock production system.

Grassland based livestock production : Grassland based livestock production depends on plant material such as shrub land, rangeland, and pastures for feeding ruminant animals. Outside nutrient inputs may be used, however manure is returned directly to the grassland as a major nutrient source. This system is particularly important in areas where crop production is not feasible because of climate or soil, representing 30-40 million pastoralists [7]. Mixed production systems use grassland, fodder crops and grain feed crops as feed for ruminant and monogastic (one stomach; mainly chickens and pigs) livestock. Manure is typically recycled in mixed systems as a fertilizer for crops. Approximately $68 \%$ of all agricultural land is permanent pastures used in the production of livestock. Landless systems rely upon feed from outside the farm, representing the de-linking of crop and livestock production found more prevalently in OECD member countries. In the U.S., $70 \%$ of the grain grown is fed to animals on feedlots." [7]

\section{Biotechnology and Agriculture}

Recent centuries witnessed high level of specialized and concentrated agriculture based on the use of machines, agricultural chemical technologies like fertilizers and pesticides, and plant breeding (hybrids and GMOs). In recent decades, sustainable agriculture became the most sought-after means to attain development coupling ideas of socio-economic justice, resource conservation and environment in the farming system $[9,10]$. This triggered solutions to problems of conventional agriculture approaches and the growth of agricultural diversification bringing about organic agriculture, community supported agriculture, urban agriculture, ecological or biological agriculture, holistic management and integrated farming system.

Since time immemorial, farming practices have embraced genetic modification of grown crops through selection of specie with characteristics like fast growth rate, larger seeds or sweeter fruits which make the features of domesticated plant species different from the wild relatives. It may therefore be affirmed that many of our modern crops were developed by farmers who are considered to have lacked an understanding of the scientific basis of plant breeding. Most of who are unrecognized or unknown to the academic environment.

Record has it that in ancient time, there exist flakes of what is today known as Biotechnology. The ancient Egyptians invented scientific processes such as the fermentation and breeding practices. Other early records include; $1750 \mathrm{BC}$ - The Sumerians brew beer; $500 \mathrm{BC}$-The Chinese use moldy soybean curds as an antibiotic to treat boils; 250 BC- The Greeks practice crop rotation to maximize soil fertility; 100 BC-Powdered chrysanthemum is used in China as an insecticide etc. (Timeline of Biotechnology above).

\section{Plant Breeding}

Early civilization was strongly base on agriculture and as such a the need for alteration of crop which has been a longstanding practice which is traceable to $2500-2000 \mathrm{BC}$ as recorded that in Africa the ancient Egyptians, apart from breeding of animals like geese and cattle for dietary and nutritional use in their society, produced wine using fermentation techniques with the aid of the microbiological processes in the absence of oxygen. The fermentation technology was equally used in bakery to provoke dough rise which consequently brought about 50 varieties of bread over 4,000 years ago.

In the $17^{\text {th }}$ century, advance plants study and the understanding were relatively poor. Nonetheless, breeding of plant was a popular practice when the study of Gregor Mendel, "the father of genetics" who was a plant breeder, on inheritable traits of peas spore a better understanding of genetic inheritance bringing about a new terminology called crossbreeding which is today referred to as hybridization. Furthermore, he published a paper in 1865 called Versuche über Pflanzenhybriden (Experiments on Plant Hybridization) at two meetings of the Natural History Society of Brünn in Moravia which was criticized, but seen as merely useful to hybridization rather than inheritance and as such ignored. In this paper distinctively demonstrated how dominant and recessive alleles produce their notable traits and possibly transfer this to offspring.

In 1900, the work was rediscovered by a group of scientists who were working on breeding problems and made Medel's findings more popular. Thereafter, major advances in plant breeding were achieved with reference to Mendel study and new understanding of genetics found tangential points to the traditional self-pollination and crosspollination techniques.

The identification of traits and their incorporating is crucial in plant breeding. Therefore breeders toured around foreign lands in search of plants with specific desirable traits. Occasionally, these traits emerge through the mutation process which was rather considered too slow and unreliable for the desired rate of production of diverse plants. This gesture of domestication of plants further became the most important means of increasing yield, improving disease resistance and drought tolerance, ameliorated nutrition and taste of crop as well as easing their harvests for centuries. Remarkably, The Green Revolution played a vital role in popularizing the use of conventional hybridization to multiply yields into many folds through "high-yielding varieties" and has a huge impact on the world's crop production.

\section{Modern Biotechnology and Agriculture (Modern GMO)}

A Genetically Modified Organism (GMO) is that whose genetic material is altered using genetic engineering techniques called recombinant DNA technology. Modern Genetic engineering has provided a wide range of genes which are valuable in the creation of 
desired germilines for new crops. A good account of this progress is traceable to the use of genetic engineering to better tomatoes so they can be more resistant to mechanical handling which was stimulated by the emergence of mechanical tomato-harvester in the early 1960 s. Genetic engineering has also helped immensely in recent creation of crops with various beneficial and development traits like flavors and aromas, sizes, harvest durability, colors, tastes, resistance etc.

\section{Herbicide-Tolerant GMO Crops}

One of the major problems of cropping systems is the attack of pests and unwanted and sabotaging weeds. A long combating solution to this is the herbicide use in the farms. Herbicides (weed killers) are pesticides applicable to unwanted plants and may be used to target specific kind of plants. According to the United State Department of Agriculture Natural Resources Conservation Service, $70 \%$ of the overall agriculture pesticide use and landscape turf management are based on herbicides [11]. Herbicides have proven to be the most probable solution, but recently, a deeper study into Genomic Engineering tend to bring more affordable proposals of seeds that are herbicide tolerant.

An example of the herbicide tolerant seed is The Roundup Ready seed. It is today grown around the world, possesses an herbicide resistant gene, built with modern genetic engineering, in its genome which enables plants to tolerate exposure to glyphosate. The Roundup Ready technology permits growing of a crop that can withstand direct contact with herbicides especially glyphosate, while combating weeds. In other words, with RR seed one can spray the farm with glyphosate to curb the weed without damaging the genetically modified herbicidetolerant crop. A suitable sample is RR soybean which accounts for $92 \%$ of the US soybeans acreage.

Notwithstanding, there are record of cases that some weeds have developed resistance to glyphosate amongst other crop deficiencies complaints, leaving farmers with little or no option than switching to other herbicides.

\section{Insect-Resistant GMO Crops}

The Insect-Resistant Plant is other kind of grown genetic engineered crops which possesses a gene from soil Bacillus thuringiensis (Bt) bacterium, that releases a specific toxin against insects protecting the plant against attacks by insects. This kind of technology already is being used in the starlink crops for example. However, it has also been argued that similar or better pest-resistance traits can be achieved by traditional breeding practices and hybridization or cross-pollination with wild species can bring about plant resistance to various pests. Furthermore, some wild species seldom present the primary source of resistance traits. A good example is some tomato cultivar with wild species traits that have gained resistance to over 19 diseases and have done so by crossing with wild populations of tomatoes.

\section{Genetic Engineering and GM Crops}

For the past 30 years, agricultural biotech has strived rapidly owing to the better understanding of DNA as the chemical double-helix code to genes creation. It is one of the most modern tools in agriculture based on recombinant DNA technology. This involves the use of tools and enzyme to cut out, insert, and modify pieces of DNA that present interesting genes. However, the main distinction between the mutation in the traditional plant breeding and genetic engineering is in the ability to manipulate individual gene and transfer gene between species which cannot be derive naturally in the wild. More so, in the traditional or conventional plant breeding, there are slim chances of obtaining any particular desired gene combination from the millions of crosses generated in the process. There can be transfer of undesired genes with the desired genes or loss of some desired genes from both parents due to the random re-assorting of their genes by the offspring, limiting the chances of improvements (Figure 1).

\section{Process of Genetic Engineering}

Genetic engineering on the other hand enables the direct transfer of one or specific set of genes between closely or distantly related organisms. Nevertheless, genetic engineering doesn't only involve inserting DNA from other organisms, but may also involve reduction or switching off specific genes, thereby controlling the undesired genes.

\section{Application of genetic engineering in crop production}

Genetic engineering techniques are applicable when all related techniques are assumed exhausted and when:

a) The trait to be introduced is not present in the germplasm of the crop;

b) The trait is very difficult to improve by conventional breeding methods; and

c) It will take a very long time to introduce and/or improve such trait in the crop by conventional breeding methods (Figure 2)

It is worth saying that modern plant breeding has paved way for multi-disciplinary process where a wide range of tools and elements of conventional breeding techniques and bioinformatics, molecular biology, molecular genetics, genetic engineering, biochemistry, biochemistry are integrated.

\section{Development of transgenic crops}

Genetic engineering has its reasonable and basic principles despite the diverse and complex techniques involved. However, it is crucially important to identify the biochemical and physiological mechanisms of action, regulation of gene expression and safety of gene and gene product to be utilized. The process of genetic engineering requires the successful completion of a series of six steps.

Step 1-Nucleic acid (DNA/RNA) extraction: Nucleic acid extraction, either DNA or ribonucleic acid (RNA) is the first step in the genetic engineering process. It is therefore important that reliable methods are available for isolating these components from the cell. In any isolation procedure, the initial step is the disruption of the cell of the desired organism, which may be viral, bacterial or plant cells, in order

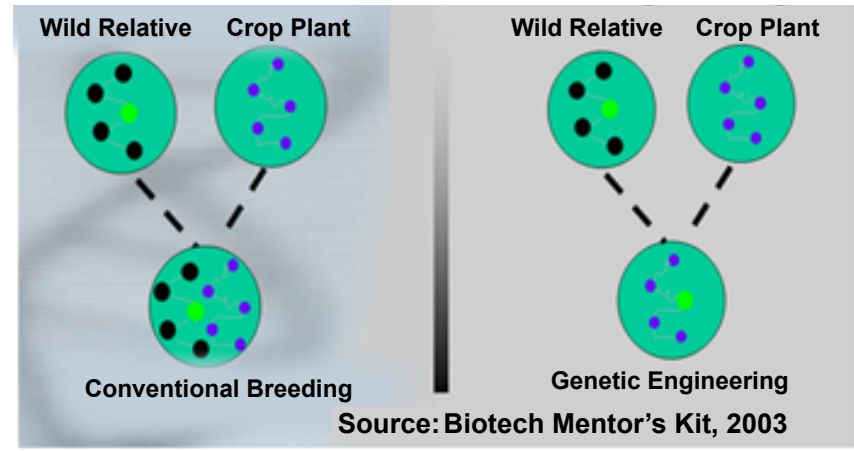

Figure 1: Conventional vs. Genetic engineering (Source Biotech Mentor's Kit, 2003) 
to extract the nucleic acid. After a series of chemical and biochemical steps, the extracted nucleic acid can be precipitated to form thread-like pellets of DNA/RNA.

Step 2-The second step is gene cloning: There are basically four stages in any cloning experiment: generation of DNA fragments, joining to a vector, propagation in a host cell, and selection of the required sequence. In DNA extraction, all DNA from the desired organism is extracted. This genomic DNA is treated with specific enzymes called restriction enzymes cutting it into smaller fragments with defined ends to allow it to be cloned into bacterial vectors. Copies of the vector will then harbor many different inserts of the genome. These vectors are transformed into bacterial cells and thousands of copies are produced (Figure 3).

Step 3-Gene design and packaging: Once the gene of interest has been cloned, it has to be linked to pieces of DNA that will control its expression inside the plant cell (Figure 9). These pieces of DNA will switch on (promoter) and off (terminator) the expression of the gene inserted. Gene designing/packaging can be done by replacing an existing promoter with a new one, incorporating a selectable marker

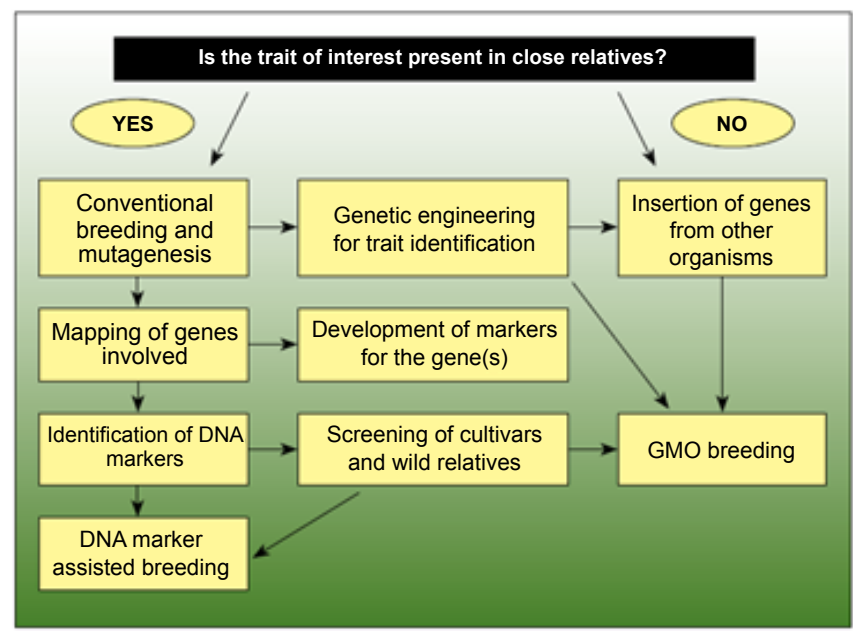

Figure 2: Genetic Engineering Process

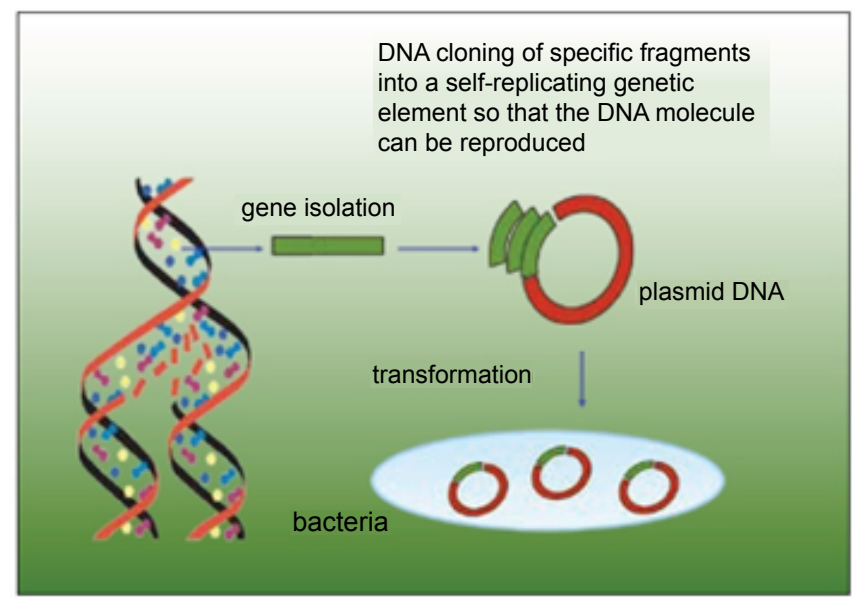

Figure 3: DNA cloning of specific fragments into a self-replicating genetic element so that the DNA molecule can be reproduced. gene and reporter gene, adding gene enhancer fragments, introns, and organelle-localizing sequences, among others.

Promoters: Promoters allow differential expression of genes. For instance some promoters cause the inserted genes to be expressed all the time, in all parts of the plant (constitutive) whereas others allow expression only at certain stages of plant growth, in certain plant tissues, or in response to external environmental signals. The amount of the gene product to be expressed is also controlled by the promoter. Some promoters are weak, whereas others are strong. Controlling the gene expression is an advantage in developing GM plants."

\section{Current Statistics and the Future of Biotechnology and Agriculture}

\section{Biotech crops surge over 1 billion hectares}

Developing nations drive growth at adoption rates exceeding industrialized countries. According to Clive James, 2010, "the 1 billionth hectare was planted in 2010 by one of the 15.4 million farmers in 29 countries who now benefit from the technology. For comparison, 1 billion hectares is roughly equivalent to the vast land area of China, or of the United States. With an unprecedented 87-fold increase between 1996 and 2010, biotech crops are the fastest-adopted crop technology in the history of modern agriculture. Growth remains strong, with biotech hectarage increasing 14 million hectares -- or 10 percent - between 2009 and 2010" (Figure 4)

For the first time, in 2010, the ten largest biotech crop growing countries all had more than 1 million hectares in production, providing a broad and stable base for future growth. In hectarage rank order, they include: USA (66.8 million), Brazil (25.4 million), Argentina (22.9 million), India (9.4 million), Canada (8.8 million), China (3.5 million), Paraguay (2.6 million), Pakistan (2.4 million), South Africa (2.2 million) and Uruguay (1.1 million) (Figure 5).

Clive James report further portrays that "for the second consecutive year, Brazil had the world's largest year-over-year increase in absolute biotech crop plantings, adding 4 million hectares in 2010 -- a 19 percent increase to grow a total of 25.4 million hectares. Only the United States leads Brazil in total cropland devoted to biotech crops. Australia, which recovered from a multi-year drought, saw the largest proportional yearon-year increase in biotech crop plantings at 184 percent. Burkina Faso followed at 126 percent growth with 80,000 farmers planting 260,000 hectares, a 65 percent adoption rate (Figure 6).

Brazil, after expediting approvals of biotech crops (a total of 27, and 8 in 2010 alone) and securing export trade agreements, now plants 17 percent of the world's biotech crops. Productivity increases attributed to biotech crops helped fuel Brazil's ability to double its annual grain production since 1990 while increasing cropland by only 27 percent. The benefits from biotech crops are spurring strong political will and substantial new R \& D investments in biotech crops, with speed and effectiveness increasing access to technology, Gomes noted. With an ability to bring up to 100 million more hectares of cropland, with water, into production, Brazil will continue to be a driving force in the global adoption of biotech crops and is investing in infrastructure to support that growth (Figure 7).

Developing countries grew 48 percent of global biotech crops in 2010 and will exceed industrialized nations in their plantings of biotech crops by 2015. Clearly, the countries of Latin America and Asia will drive the most dramatic increases in global hectares planted to biotech crops during the remainder of the technology's second decade of commercialization (Figure 8). 


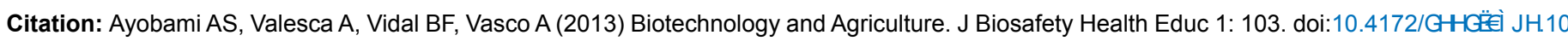
00103

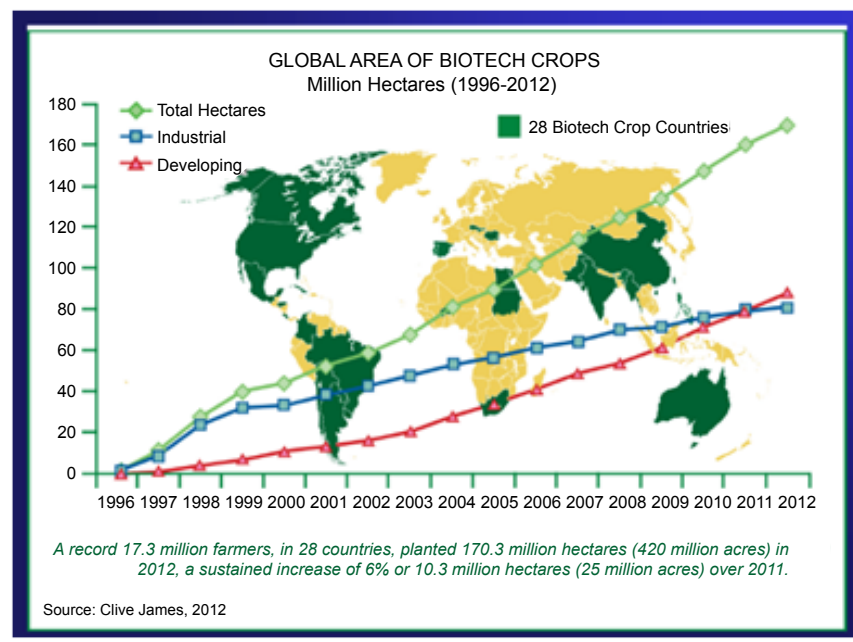

Figure 4: Global area of Biotech crops-Million Hectares (1996-2012) (Source: Cleve James, 2012)

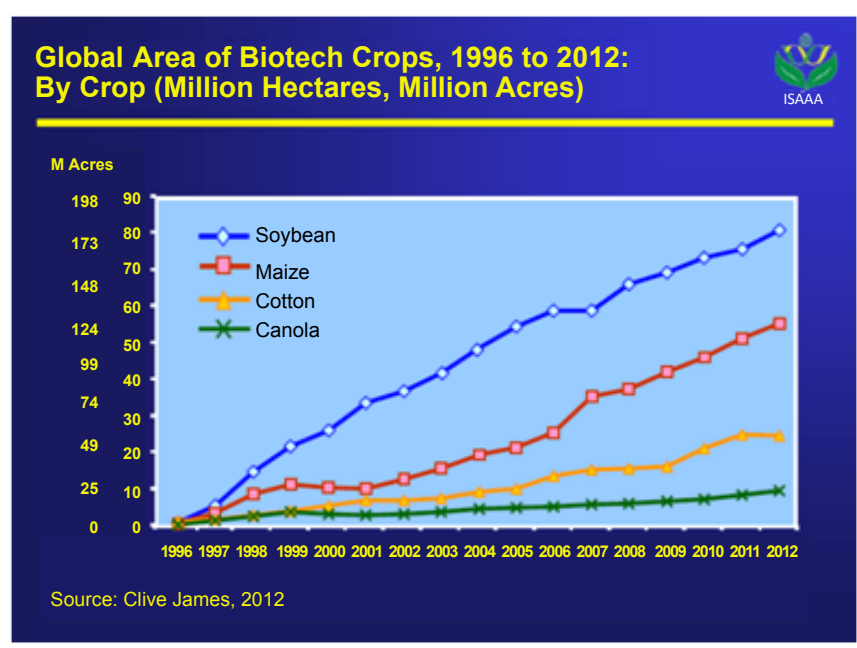

Figure 5: Global area of Biotech Crops, 1996 to 2012: by Crop (Million Hectares, Million Acres) (Source: Cleve James, 2012)

The five principal developing countries growing biotech crops China, India, Brazil, Argentina and South Africa - planted 63 million hectares of biotech crops in 2010, equivalent to 43 percent of the global total. All told, 19 of the 29 countries that have adopted biotech crops are developing nations, which grew at a rate of 17 percent or 10.2 million hectares over 2009 compared to only 5 percent growth or 3.8 million hectares in industrialized countries" (Figure 9).

\section{Merits of modern biotechnology and agriculture}

The merits of modern Biotech and agriculture include:

Safety: Agriculture as an industry works hand in hand with the government agencies and some other organizations to guarantee farmers' access to necessary technologies and ensuring modern agriculture system. Farmers can be aided by education and certification programs that ensure careful application of agricultural practices and avoid malpractices.

Sustainability: this advancement in technology provides farmers with useful tools and resources to improve sustainable farming and limit environmental footprint. It has also incentivized innovations like conservation tillage as prevention against erosion, water pollution and promotes carbon sequestration.

Affordability: Modern technology system promotes affordable supply of food to attend to the demand of the world's growing population. Modern agriculture practice also permits large production utilizing smaller pieces of land in order to reduce cost of production.

\section{Demerits of modern biotechnology and agriculture}

- The British Medical Association has reported that antibiotic resistant marker genes inserted into specific crops could provoke microbes that cause diseases in the humans' or other animals' gut as it would lead to the microbes becoming antibiotics resistant thereby compounding public health problem of antibiotic resistance.

- Foreign genes are known to alter nutritional value of foods in unpredicted manner. It may reduce some nutrients values while increasing the level of some others and there are fewer findings

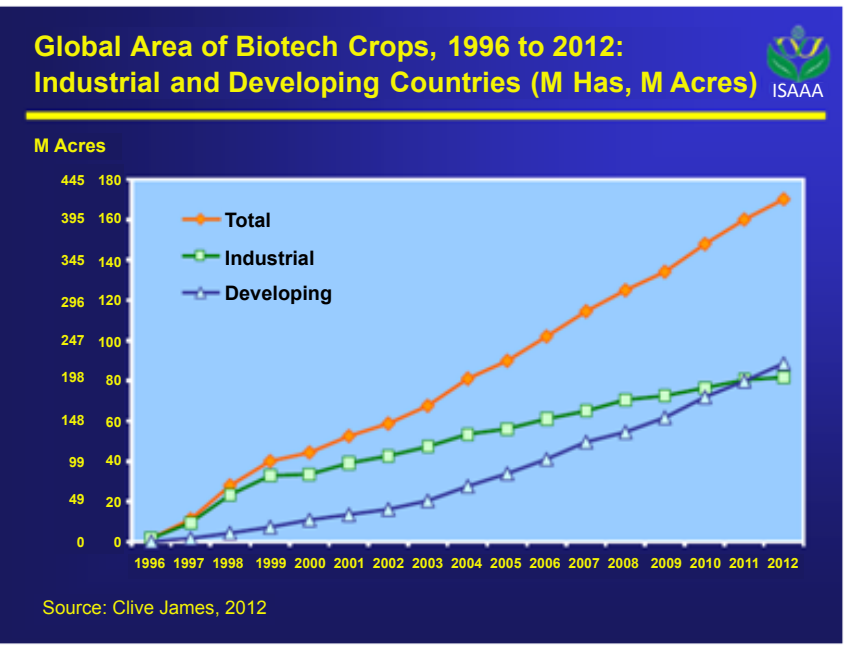

Figure 6: Global area of Biotech crops, 1996 to 2012: Industrial and Developing countries (M Has, M Acres) (Source: Cleve James, 2012)

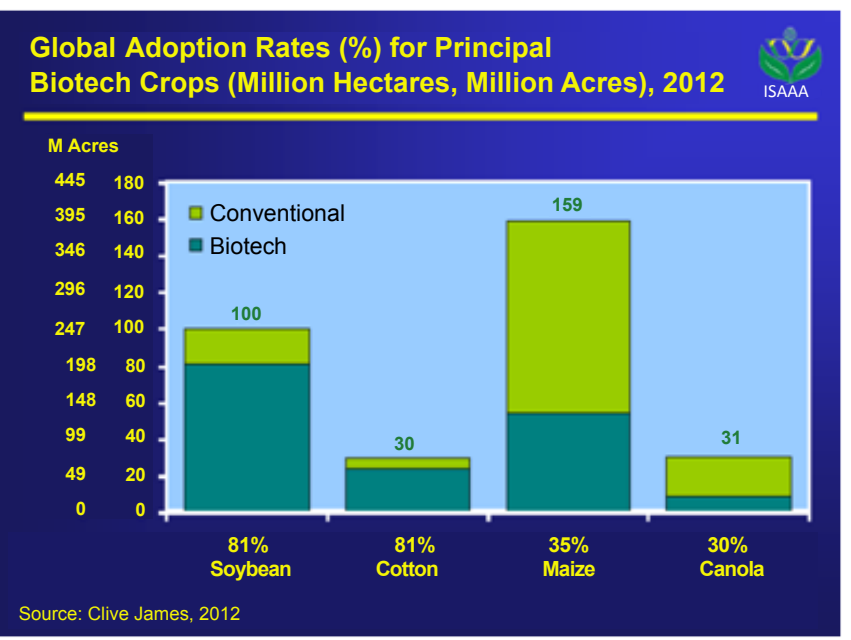

Figure 7: Global Adoption Rates (\%) for principal biotech crops (Million Hectare, Million Acres), 2012 (Source: Cleve James, 2012) 
into the effect of changes in nutrient composition of food plant and animals.

- Genetic modification of food plants could transfer allergenic properties of the donor source into the recipient plant or animal. In addition, many genetically engineered foods use microorganisms as donors whose allergenic potential are either unknown or untested.

- Genetically modified crops having herbicide and insect resistance could cross-pollinate with wild species, and unintentionally create hard to-eradicate super-weeds especially in small farm fields surrounded by wild plants. This

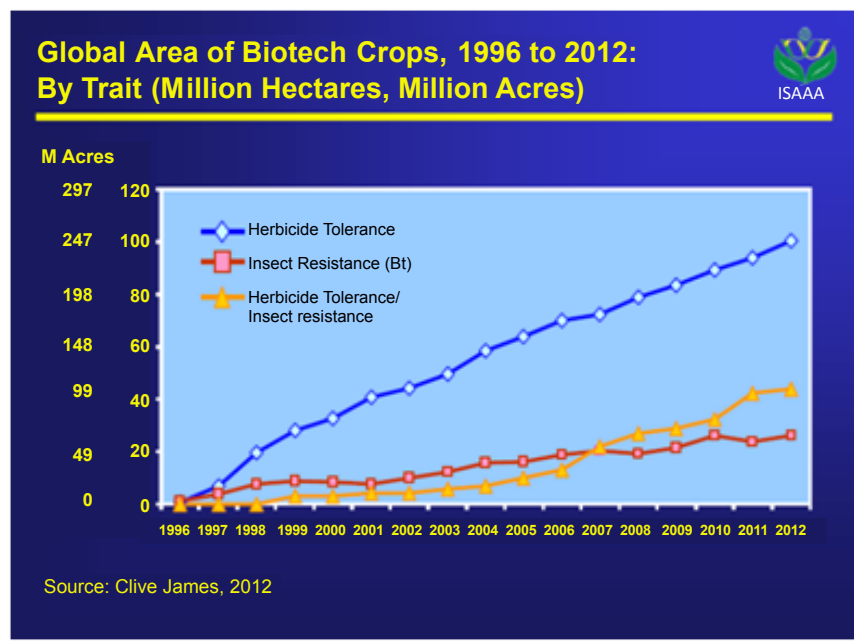

Figure 8: Global area of biotech crops, 1996 to 2012: by Trait (Million Hectares, Million Acres) (Source: Cleve James, 2012)

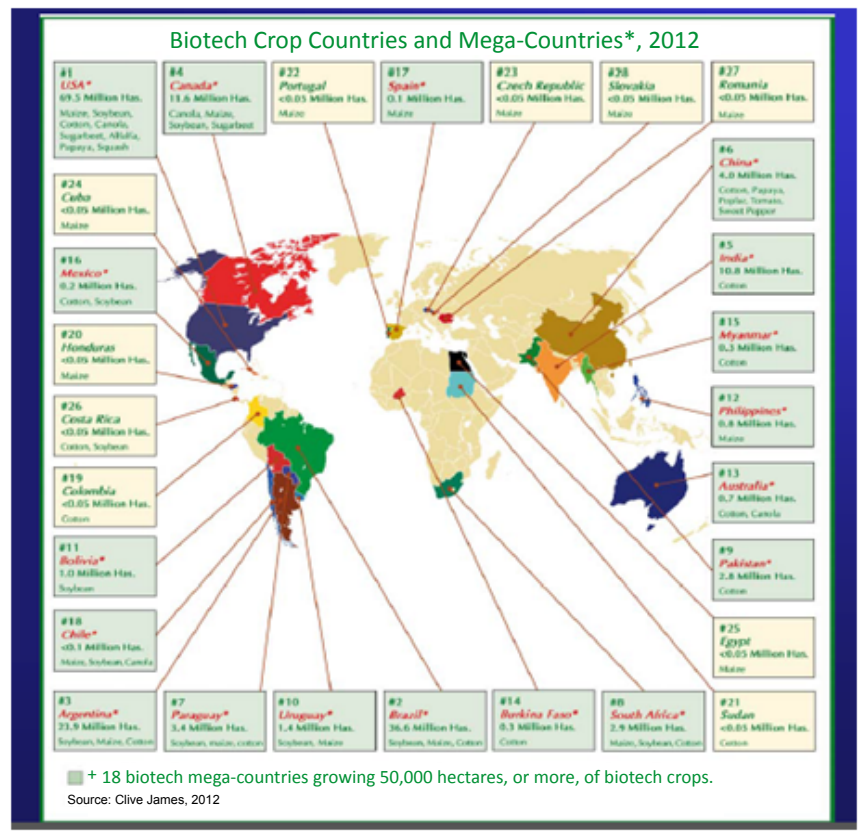

*18 Biotech mega-countries growing 50, 000 hectares, or more, of biotech crops. Figure 9: Biotech Crops Countries and Mega-Countries* (Source: Cleve James, 2012) unintentional gene transfer, although hard to substantiate, can have consequences that are not yet known.

- Genetic modification could inadvertently enhance natural plant toxins by switching on a gene that has both the desired effect and capacity to pump out a poison.

- Religious concerns are also voiced as some of the reasons for opposing genetic engineering of foods, while some people object to bio-engineered foods for personal, ethical, cultural, and esthetic reasons, as well as infringement on consumer choice, and inability to distinguish GM foods from non-GM counterparts.

- Critics of genetic modification of foods fear that commercialization of transgenic crops

- Will pose a new threat to crop genetic diversity already endangered by current agricultural practices that favor the worldwide adoption of a few crop varieties.

- Plants engineered to contain virus particles as part of a strategy to enhance resistance could facilitate the creation of new viruses in the environment.

- Some critics of genetic modification argue that patenting allows corporations to have monopoly control of genetically altered plants or animals.

- Animal rights groups strongly oppose any form of cloning or genetic engineering involving animals, or use of animals in research, and have sometimes resorted to vandalizing animal research.

- Many critics are concerned that GM foods are not labeled. They insist that labeling can help the consumer trace unintended consequences to a certain consumed GM food.

- Consumers also have a genuine 'fear of the unknown' in that deadly microorganisms or super plants might be released during field testing or field trials, and accidents in biotech labs might lead to release of toxic agents, poisons, or biological toxins which will threaten human and animal populations.

- Organic farmers fear that GM foods would obscure organic foods because of lack of labeling, and they feel that the biotech revolution could make it difficult for people to locate non-GM crops.

Using information relating to specific molecular marker sequences and the desired phenotype, the vector harboring the desired sequence is detected, selected, isolated and clones are produced. Restriction enzymes are again utilized to determine if the desired gene insert was cloned completely and correctly.

\section{Conclusion}

New nations are around the world opt for the planting of biotech crops. ISAAA 2010 report shows that approximately 600,000 farmers in Pakistan and 375,000 farmers in Myanmar, planted insect-resistant Bt cotton, and Sweden have started planting a new biotech high-quality starch potato approved for industrial and feed use. Germany also planted the same biotech potatoes in 2010, resuming its place among the eight EU nations now growing either biotech maize or potatoes.

Many more companies are expected to adopt biotech crops in the nearest future as the number of growers and global hectarage of 
biotech crops are also expected to increase tremendously. It has also been stimulated that at least three more countries from each of the three regions of Asia, West Africa, East/Southern Africa and some few others from Latin/Central America, and Western/Eastern Europe will grow more of biotech crops according to the ISAAA 2010 publication. In 2010, Mexico which is notable for its variety of maize has also embarked some field trials of $\mathrm{Bt}$ and herbicide tolerant maize which was reportedly successful.

In 2010, ISAAA further emphasized the potential for increasing the biotech adoption for four main and current large hecterage biotech crops which include maize, soybeans, cotton and canola which also are reported to have represented almost 150 million hectares in 2010 being a half way attained capacity of the hectarage around the world. It was also demonstrated in the same research that the 29 countries which planted biotech crops in 2010 represented 59 percent of the world population, and as such argued that its 2015 Millennium Development Goals could find solution to food security and poverty problems and would be made popular around the world. However, there being to side to a coin, it is advisable to have a well scrutinized and checkmated biotechnology practice as well as related agriculture practices. Therefore, every national and international agency as well as the governing bodies should ensure control and protection against its abuse.

\section{References}

1. Brady NC, Weil RR (2002) Practical Nutrient Management. Elements of the
Nature and Properties of Soils, Pearson Prentice Hall, Upper Saddle River, NJ, USA.

2. Acquaah G (2002) Land Preparation and Farm Energy. Principles of Crop Production, Theories, Techniques and Technology. Prentice Hall, Upper Saddle River, NJ, USA.

3. Acquaah G (2002) Pesticide Use in U.S. Crop Production. Principles of Crop Production, Theories, Techniques and Technology. Prentice Hall, Upper Saddle River, NJ, USA.

4. Acquaah, G (2002) Soil and Land. Principles of Crop Production, Theories, Techniques and Technology. Prentice Hall, Upper Saddle River, NJ, USA.

5. Chrispeels MJ Sadava DE (1994) Farming Systems: Development, Productivity and Sustainability. Plants, Genes, and Agriculture. Jones and Bartlett, Boston, USA.

6. Brady NC, Weil RR (2002) Elements of the Nature and Properties of Soils Pearson Prentice Hall, Upper Saddle River, NJ.

7. Chrispeels MJ Sadava DE (1994) Nutrition from the Soil. Plants, Genes, and Agriculture. Jones and Bartlett, Boston, MA, USA.

8. Acquaah G (2002) Plants and Soil Water. Principles of Crop Production Theories, Techniques and Technology. Prentice Hall, Upper Saddle River, NJ.

9. Gold MV (1999) Sustainable Agriculture: Definitions and Terms. USDA National Agriculture Library. Beltsville, MD.

10. Earles R, Williams P (2005) ATTRA National Sustainable Agriculture Information Service.

11. Kellogg RL, Nehring R, Grube A, Goss DW, Plotkin S (2000) Environmental indicators of pesticide leaching and runoff from farm fields. United States Department of Agriculture Natural Resources Conservation Service. 